\title{
STEM Education through Making: What Are Affordances and Challenges of Making Out of School Club?
}

\author{
Deqi Zhang \\ King's College London, London, UK \\ Email: deqizhang@yahoo.com
}

How to cite this paper: Zhang, D. Q. (2021). STEM Education through Making: What Are Affordances and Challenges of Making Out of School Club? Open Journal of Social Sciences, 9, 572-583. https://doi.org/10.4236/jss.2021.99042

Received: April 7, 2021

Accepted: September 26, 2021

Published: September 29, 2021

\begin{abstract}
Making has been considered as an important way to effectively promote STEM education in informal learning environment. Making is growing and gradually presents a number of affordances that are conducive to STEM teaching and learning. However, studying STEM through Making within out-of-school context is still not fully mature, so STEM educators are facing challenges. Based on constructionism and embodied cognition, this essay will discuss affordances from three perspectives (constructionism pedagogy, engagement in STEM-related practice and playfulness). The current challenges about learners' participation and assessment are also analyzed. Aiming at current challenges, suggested teaching and assessment methods are put forward.
\end{abstract}

\section{Keywords}

Making, Out-of-School Context, STEM Education, Challenges, Affordances

\section{Introduction}

The Maker movement has made significant progress in the informal field of STEM education (Ladeji-Osias \& Partlow, 2017). National Research Council (2015) has also indicated that becoming productive from out of school learning opportunities for young people is a key part of the STEM learning ecosystem. Making has been regarded as a mechanism to promote STEM learning by the education community due to its driving effect on creativity and innovation (Marshall \& Harron, 2018). However, while there is plenty of support for conducting a Making out of school club, educators still face challenges. 
The popularity of Making movement brings opportunities as well as challenges to STEM teaching. This essay will discuss affordances of out-of-school Making activities through the theoretical lens of constructionism and embodied cognition. The challenges out of school context relating to learners' different participation and assessment will also be addressed. Finally, aiming at those challenges, this essay will propose and analyze current potential solutions.

\section{Constructionism as a foundation}

In a nutshell, the definition of constructionism is obtaining knowledge through making (Papert, 1986; Papert \& Harel, 1991). From the perspective of the constructivist theory of psychology, Papert (1986) believed that learning is a kind of reconstruction, rather than the transmission of knowledge. Constructing meaningful products is one of the most effective way to learn (Papert, 1986). People can learn most effectively when they are making something tangible actively in the real world. Different from Piaget's constructivism (explaining how children's behaviors and ways of thinking change over time), Papert's constructionism focuses more on making and creating in learning (Papert \& Harel, 1991; Ackermann, 2001). For example, at the Muzzey Junior High School in Lexington, children received good math training from building a soap sculpture (Papert \& Harel, 1991). Papert and Harel (1991: p. 4) even used poetic language to describe this process of making as allowing children "to think, to dream, to gaze, to get a new idea and try it". Unlike traditional math classes, children engage in playing and creating with their own ideas, and then, this would lead to an increase of their knowledge and the ability to identify with it. Constructionism describes the learning process, not only in terms of intelligence, but also in terms of learners' emotions (ibid.).

\section{Embodied cognition and Making}

Wilson (2002) argued that people have evolved from creatures whose neural resources were used mainly for perceptual and motoric processing, and whose cognitive activities are the interaction with the environment. Therefore, sensory-motor processes and physical properties of the body are the foundation of human cognition (Lonescu, \& Vasc, 2014). In other words, embodied cognition represents how people process and store information. That is, the cognitive process is deeply rooted in the interaction between the body and the world (ibid.). Wilson (2002) also proposed that the environment is part of cognition. People's thinking and decision-making are affected by the real environment, which is the product of the interaction between mind and environment (ibid.). For example, this is best shown in infants. Infants learn more about the environment using their innate skills and abilities, such as sucking, grasping and listening (ibid.). Therefore, when using the concept of embodied cognition to understand the studying process, practicing and tinkering should take precedence over memorization and understanding the knowledge in textbooks (Claxton, 2015). 


\section{The Affordances of Making Out of School Club}

\subsection{Constructionism Pedagogy}

Out-of-school Making is based on the constructionism pedagogy, which provides a more effective way to support learning. According to Petrich, Wilkinson, and Bevan (2013), the pedagogical design for Making draws on constructionism theory. Learning in a Making club is not like imparting knowledge in traditional lecture, but rather, learners think and learn with their hands (ibid.). The learning process in out-of-school Making can be described as exploring something new, and then testing their ideas, and finally being able to make something tangible with their hands (ibid.).

Then, the constructionism pedagogy in Making clubs support the framework of the $21^{\text {st }}$ century to learn more effectively. Taylor (2016) pointed out that Making let young people design their ideas digitally, but they can also turn them into reality. During this process, learners' relevant skills can also be strengthened. For example, Peppler et al. (2015) and Taylor (2016) concluded a survey aiming at three out-of-school makerspaces in the USA and Korea and respondents are from 51 youth-oriented makerspaces. The data of this survey reflected how Making support $21^{\text {st }}$ century learning and career skills (Figure 1). It is clear to see from this table that most learners can be engaged in developing creativity, collaboration, problem solving, adaptability, and initiative in a makerspace very frequently, even multiple times per week.

The development of those skills is beneficial from the constructionism pedagogy of those makerspaces. According to Taylor (2016), makerspaces provide young people with opportunities to construct and think. Making is not only a hands-on process. During Making, learners are encouraged to discover, critically

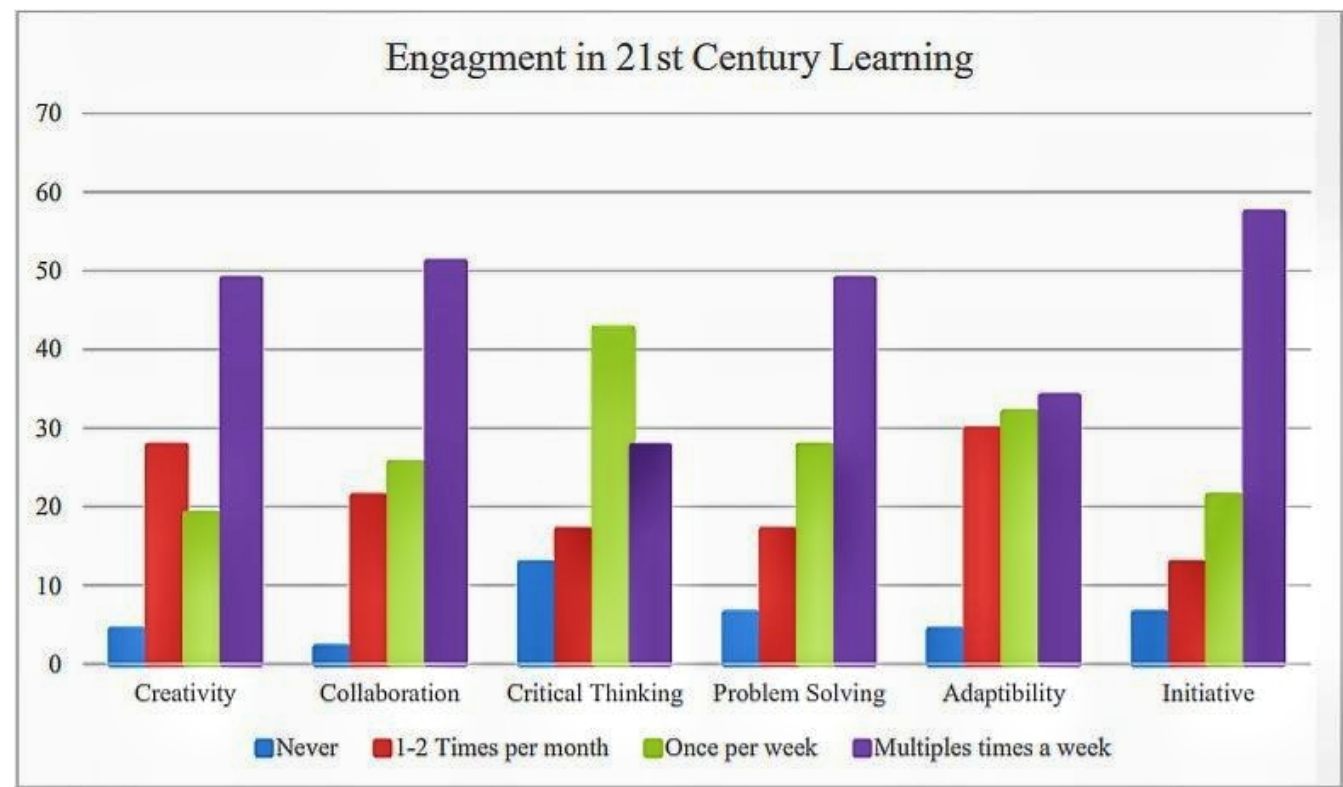

Figure 1. Frequency of Sites Reporting Engaging in 21st century learning and career skills (Peppler et al., 2015; Taylor, 2016). 
analyze and collaborate with their colleagues. They may form a group to explore new ideas, identify and resolve problems, and finally complete their programs or products (ibid.).

\subsection{A More Powerful Way to Engage in STEM-related Practice}

Making activities in the environment outside school provides learners with a more powerful way to engage in STEM-related practice. Firstly, making out of school has more possibilities and authenticity in the learning environment. For example, Petrich, Wilkinson, and Bevan (2013) described what Making activities they observed out of school context. Learners can play with simple circuits and learn about switches and parallel circuits in an electricity-themed repair studio. At another station, learners may even sit in a sewing circle, sewing belts, scarves with conductive thread, and designing bag circuits that integrate LEDs, button batteries and electricity (ibid.). Out-of-school Making is "a new kind of public learning experience", where learners' amazing concentration, creativity, perseverance and pride are illustrated (Petrich, Wilkinson, \& Bevan, 2013: p. 51). Furthermore, learners in Making club can use their understanding and imagination to develop what they think of into something concrete (Petrich, Wilkinson, \& Bevan, 2013).

According to Wilson (2002) and Claxton (2015), the theory of embodied cognition emphasizes that cognitive activities interact with the environment. The theory of embodied cognition can explain why Making clubs can provide a more powerful engagement. When the concept of concrete cognition is used to understand the learning process, practice and repair in the learning environment should take precedence over memory and understanding of knowledge in textbooks (ibid.). Based on embodied cognition, the affordance of Making out of school context is that it provides a better environment where learners can make and create. Learners can study circuits in an electrical themed lab or in a sewing ring at a station. Braund and Reiss (2006) also proposed that out-of-school contexts should be seen as complementary to formal learning because the authenticity of out-of-school Making environment is more correspond the experience of scientists and technicians in the scientific real world. This environment also deepens learners' engagement in their work at hand. For example, based on an observation of Petrich, Wilkinson, and Bevan (2013) towards a Tinkering studio, learners often spend on ideas for an hour, sometimes half a day, and many of them return regularly as the theme changes. "Such a rich spirit of joy and dedication inspires us and keeps us going" (Petrich, Wilkinson, \& Bevan, 2013: p. 52). Therefore, Making activities out of school provides an opportunity where learners can interact with "real" environment to learn. This is a more powerful way to engage learners into learning (ibid.)

\subsection{Playfulness of Making}

In Making activities, especially for out-of-school context, play has an important 
role. First of all, the playfulness involved in Making is a kind of intrinsic motivation for learners. For a long time, play has been recognized as a central key to children's development (Piaget, 1962; Bodrova, Germeroth, \& Leong, 2013). As Sheridan (1977) said, children are eager to devote themselves to joyful physical and mental activities to obtain emotional satisfaction. Dougherty (2013) stated that the heart of Making is experimental play. How to understand the "experimental play" in Making? According to Gershenfeld (2005), when artists, architects and engineers create or work, it is not out of professional desire or external requirements, but because they believe that what they have created will be fun and playful. Therefore, they are willing to create and use their own inventions.

Based on the above logic, Martin (2015) concluded that the learners' intrinsic goals, interests and awareness of interesting and cool things are paramount. This is also the difference between Making and many other activities constrained by external requirements, such as a robot competition. Play, fun and interest are at the heart of Making (ibid.). Also, Vansteenkiste et al. (2004) indicated that fun, playful activities are intrinsically motivating for learners. This intrinsic motivation can bring about a variety of educational benefits. For example, learners with intrinsic motivation can hold higher persistence when they face challenges (ibid.).

Second, playful Making can stimulate students' self-efficacy and arouse their interest in learning. Before talking about self-efficacy and a learning interest, the conclusion of the previous paragraph should be referred to at first. That is, the playfulness of Making can be seen as an intrinsic motivation for learners to engage in Making. In fact, intrinsic motivation often comes together with self-efficacy and interest, because those three factors determine a person's self-concept (Chu et al., 2015). Self-concept is the sum of one's own cognition. To be more precise, in this case, whether learners finally believe that they have the ability to open the door of technology and science has a lot to do with their own self-concept (ibid.).

According to Chu et al. (2015), Making's attribution of playfulness can be seen as an intrinsic motivation for learners. Driven by intrinsic motivation, learners would have a higher interest to engage in Making. This will lead to a higher degree of engagement. Then, learners would perceive more of an ability to perform well through engagement. Next, learners would have a stronger self-efficacy in Making. The stronger self-efficacy motivates the engagement in Making (ibid.). This point can be explained by the principle of the self-efficacy theory. Self-efficacy refers to the subjective judgment of whether one can succeed in a certain thing (Bandura, 1997, 2002). The more self-efficacy people have about something, the more motivated they are to do it (ibid.). Finally, these three factors, motivation, self-efficacy and interest form a virtuous circle (Figure 2). Morocz et al. (2016) also proved that, in a survey towards engineering major, students with higher participation in Making outside school would have a higher enthusiasm for engineer design learning and a higher self-efficacy for becoming 


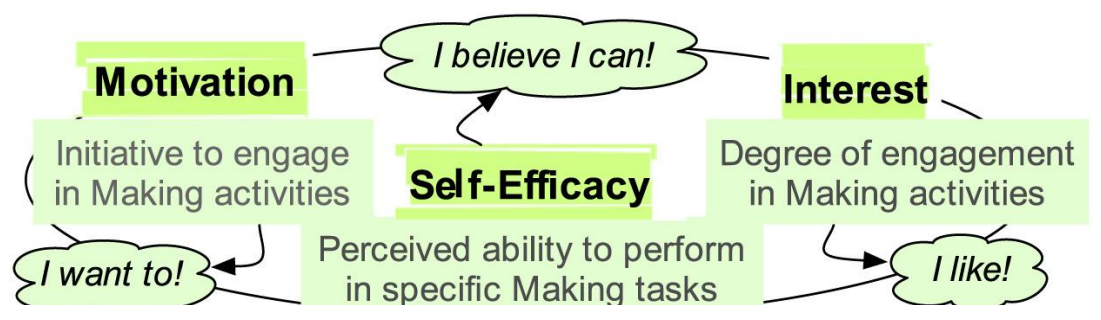

Figure 2. Key Factors Determining Maker’s Self-concept (Chu et al., 2015).

an excellent engineer in the future.

\section{Current Challenges of Making Out of School Club}

Although teaching and learning STEM through out-of-school Making clubs has many advantages mentioned above, it still faces some challenges in practice.

\subsection{Gender Difference in Making}

The current data illustrates different learners participate differently in Making learning. For example, fablab, a digital fabrication laboratory, provides access to anyone who would want to make and create what they want. As an initiative of maker culture, fablabs has a growing momentum in Europe recently (Maric, 2018). In an observation towards a fablab located in Montpellier, the gender imbalance of the participants was found (ibid.). Female participants were significantly less than male. $69 \%$ male participants were the main users of this fablab, while female learners only occupy $31 \%$ (ibid.).

Two reasons are concluded from the current literature for the situation in Making. First, males and females have different preferences in Making activities. For example, crafting, sewing, and other textile design activities can attract more females (Buechley, 2013; Buchholz et al., 2014). By contrast, males have higher interest in electronics, engineering, and robotics fields (ibid.). For instance, according to Buechley and Mako-Hill (2010: p. 202), Arduino, a popular robot toolkit, only has less than $1 \%$ female users. A perfect Making topic attracting boys and girls at the same time is still being explored. Second, apart from gender preference, the media often describes Making as a white, male, middle class pursuit movement (Buechley, 2013; Martin, Dixon, \& Betser, 2018). Media publicity may guide people's prejudice, which can build up barriers that further suppress the engagement of women and people of color.

The above reasons prove people cannot have unequal opportunities to engage in Making. Barton, Tan, and Greenberg (2017) also argued that the maker movement has not been widely successful in attracting different audiences. Making is still an adult, white, middle-class activity and the users are mainly white adult males (TASCHA, 2012).

\subsection{Assessment for Making}

Currently, the assessment for out-of-school Making activities faces challenges. 
Assessment refers to all activities carried out by teachers and students when assessing themselves, which provides information and serves as feedback for revising teaching activities (Yin et al., 2020). First of all, compared with school-based makerspaces, the assessment rate of out of school Making activities is low (Peppler et al., 2017). Peppler et al. (2017) conducted a survey aiming at school-based and out-of-school Making's assessment (Figure 3). According to the result of this survey, there is a significant difference between in-school and out-of-school spaces. $90 \%$ of school-based Making have conducted assessments, which may be due to the pressure of curriculum integration into other discipline areas and/or grading learners' work to demonstrable learning outcomes. In contrast, only $64 \%$ of out-of-school makerspaces reported using assessments in their programs (ibid.). Therefore, compared with the adequate school-based makerspace assessments, out-of-school Making assessment is far from enough.

Second, apart from the low assessment rate, the assessment type of out-of-school Making activities is also limited. For example, Peppler et al. (2017) surveyed the use of different assessment types in and out-of-school Making environment (Figure 4). Figure 4 illustrates clearly that most of the assessment types have a higher utilization rate in the school-based environment than in the out-of-school makerspaces. Rubrics are the most obvious difference in the utilization

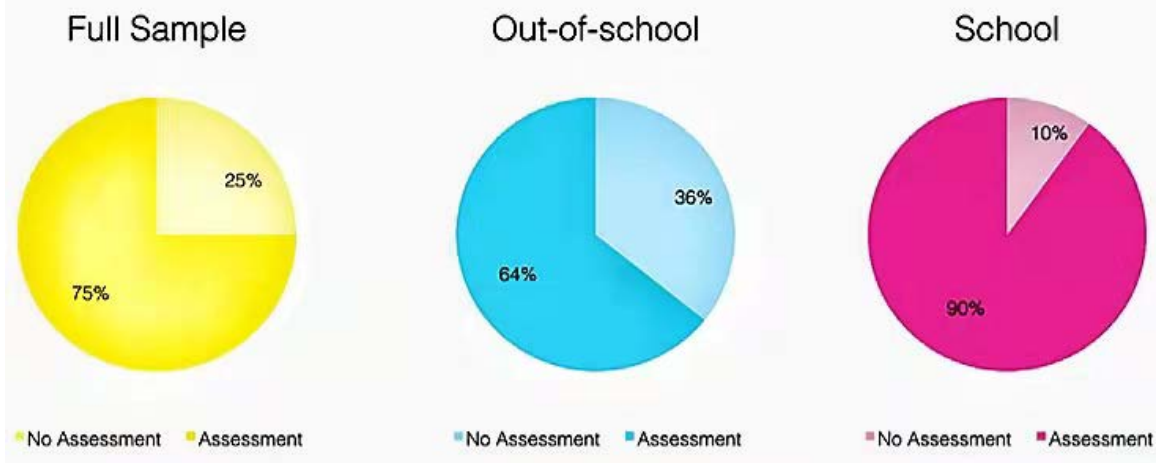

Figure 3. Assessment in out-of-school and school makerspaces (Peppler et al., 2017).

\begin{tabular}{|c|c|c|c|}
\hline & $\begin{array}{l}\text { FULL SAMPLE } \\
(N=48)\end{array}$ & $\begin{array}{l}\text { OUT-OF-SCHOOL } \\
(N=28)\end{array}$ & $\begin{array}{l}\text { SCHOOL } \\
(N=20)\end{array}$ \\
\hline SELF-ASSESSMENT & $48.0 \% \uparrow$ & $36.0 \%$ & $65.0 \% \uparrow$ \\
\hline PORTFOLIO ASSESSMENT & $35.0 \% \uparrow$ & $21.0 \%$ & $55.0 \% \uparrow$ \\
\hline EXIT SURVEY & $33.0 \% \uparrow$ & $32.0 \% \uparrow$ & $35.0 \%$ \\
\hline PEER ASSESSMENT & $33.0 \% \uparrow$ & $29.0 \% \uparrow$ & $40.0 \%$ \\
\hline RUBRICS & $29.0 \%$ & $7.0 \%$ & $60.0 \% \uparrow$ \\
\hline SHORT ANSWER QUESTIONS & $21.0 \%$ & $18.0 \%$ & $25.0 \%$ \\
\hline ADULT MODELING & $17.0 \%$ & $4.0 \% \downarrow$ & $35.0 \%$ \\
\hline PRE/POST-TESTS & $10.0 \%$ & $11.0 \%$ & $10.0 \% \downarrow$ \\
\hline ESSAY ITEMS & $6.0 \%$ & $4.0 \% \downarrow$ & $10.0 \% \downarrow$ \\
\hline MATCHING ITEMS & $2.0 \% \downarrow$ & $0.0 \% \downarrow$ & $5.0 \% \downarrow$ \\
\hline MULTIPLE CHOICE & $2.0 \%$ & $4.0 \%$ & $0.0 \% \downarrow$ \\
\hline
\end{tabular}

Note: Bolded percentages indicate most $\uparrow$ and least $\downarrow$ common responses.

Figure 4. Assessment types utilized among makerspaces (Peppler et al., 2017). 
rate between the two environments. It is clear to see from the figure that the gap between the two environments is as high as 53\%. Based on Peppler et al. (2017), the rubrics are more likely to be used in a school-based environment rather than an out of school environment, probably due to the assessment criteria needing to be planned and tested in advance. However, the out-of-school makerspaces may occur with more unexpected emergency and with urgent results, so it is more difficult to ensure all assessment criteria ahead of time (ibid.).

Third, the assessment for Making activities out of school is not always very effective. The current educational assessment methods are mainly summative assessment and formative assessment (Assessment Reform Group, 2006). The focus of summative assessment is the outcome of a program, which favors tests and scores. This contrasts with formative assessment, which summarizes the participants' development during the program (Scriven, 1967). Yin et al. (2020) also stated that formative assessment can provide descriptive feedback and guide students for further improvement.

Based on Making activities' project-based model, summative assessment is not able to measure completely and effectively a learners' performance (Yin et al., 2020). The scope of Making is broad. It focuses on designing, building, modifying, and manufacturing real and/or digital artifacts (Scriven, 1967). The first learning outcome is the acquisition for the knowledge and skills in engineering, circuit, design and computer programming (ibid.). Then, Searle and Kafai (2015) argued that Making activities have the potential to change students' attitudes towards STEM subject areas because Making provides students with more opportunities to engage in STEM. Burge et al. (2013) indicated that Making may also improve a students' confidence and ability to solve problems. Based on the above, in addition to knowledge, practical ability, cognitive and emotional learning outcomes are all the purpose of Making learning. As a result, only examinations cannot assess Making very well. A formative assessment that mainly addresses improvement is appropriate. However, Yin et al. (2020) argued that formative assessment is elusive as it has to depend on a teachers' experience and intuition to a great extent. For example, many teachers may occur to assess the "teachable moments that unexpectedly arise in the classroom". Teachers cannot predict those situations and prepare in advance. Under this situation, they have to assess only based on their previous experience (Yin et al., 2020: p. 193).

\section{Proposed Solutions}

\subsection{Applying Science Capital Teaching Approach}

Scientific capital refers to a way that includes all the knowledge, attitude, experience and social interaction that individuals may have related to science. The more scientific capital one has, the more likely one is to pursue scientific identity in one's future (Godec, King, \& Archer, 2017). The key of a science capital teaching approach is to recognize and attach importance to the existing scientific capital of students, and at the same time to help them establish a new scientific 
capital (ibid.). In this way, students' engagement can be expanded.

The foundation of science capital teaching is "broadening what counts" (Godec, King, \& Archer, 2017: p. 17). Broadening what counts means creating spaces where all students feel they can make contributions from their own experiences, interests and identities. In those spaces, students would know they will be valued (Godec, King, \& Archer, 2017). For example, teachers would create opportunities for students to express themselves in ways they feel comfortable. Teachers would also showcase examples from different types of people who work for science (ibid.). In fact, the science capital teaching approach stresses removing the barriers and changing systems that create inequality (Archer, DeWitt, \& King, 2018). The science capital teaching approach has made achievement. For example, after the first-year implementation in partner schools, the percentage of students who have an interest in studying at least one science subject at an A-level have increased remarkably from $16 \%$ to $21.4 \%$ (Archer, DeWitt, \& King, 2018: p. 7).

However, aiming at the challenge of media's misleading, capital teaching may not hinder the people's stereotype guided by media publicity. In addition, there indeed exist low-income people who have no access to STEM related resources. Therefore, as an approach mainly conducted in the classroom, even if science capital teaching is effective, it cannot achieve perfect fairness.

\subsection{Setting Formative Assessment for Making}

In order to assess a learners' performance, Yin et al. (2020) designed two formative assessment frameworks. They are a formal-and-embedded-in-curriculum formative assessment and are a planned-for-interaction formative assessment (ibid.). The formal-and-embedded-in-curriculum formative assessment is designed to be implemented after class to ensure that students achieve expected goals before entering the next unit (ibid.). As for planned-for-interaction formative assessments, it is used in the teaching process, but prepared consciously before class, so as to closely incorporate with the teaching objectives (ibid.).

For designing a planned-for-interaction formative assessment, Yin et al. (2020) firstly identified skills that should be strengthened through Making. They also positioned the time in Making activities where students can demonstrate or apply those skills (ibid.). Based on above, planned-for-interaction formative assessment was designed. Implementation methods are answering formative assessment questions and filling in worksheets that include questions prompting students to use relevant skills (ibid.). For the formal-and-embedded-in-curriculum formative assessment, the main key are integrated achievement tests and self-reported surveys at the beginning and the end of the Making to test the possible Making's impact towards learners (ibid.).

\section{Conclusion}

This essay briefly analyzes the affordances and challenges of Making activities in 
the out-of-school context. In terms of affordances, Making activities out of school can provide learners with an authentic environment to study STEM. When analyzing the environment provided by out-of-school context, the theoretical lens of embodied cognition is used. This theory stressed the operation that interaction between mind and environment leads to people's cognition. This point also proves an out-of-school context is more conducive to a students' learning compared with a formal context. Then, the constructionism pedagogy and playfulness of Making also enable learning out of school context to be positive.

As for challenges, learners' different participation and how to assess Making out of school are discussed in this essay. Then, current potential solutions aiming at those two challenges are proposed, which is the implementation of science capital teaching approach and formative assessment. Although those solutions are effective to a certain extent, they cannot solve all challenges completely. Therefore, it is suggested that the future research direction should further explore how to solve the misguidance of media on STEM and Making learning, and how to make media play the positive role. Developing formative assessment and embedding it into Making curriculum design is also the suggested direction for future research.

\section{Declaration}

This study was not supported by public or personal grants.

\section{Conflicts of Interest}

The author declares no conflicts of interest regarding the publication of this paper.

\section{References}

Ackermann, E. (2001). Piaget's Constructivism, Papert's Constructionism: What's the Difference. Future of Learning Group Publication, 5, 438.

Archer, L., DeWitt, J., \& King, H. (2018). Improving Science Participation: Five Evidence-Based Messages for Policy-Makers and Funders. London: UCL Institute of Education.

Assessment Reform Group (2006). The Role of Teachers in the Assessment of Learning. London: Institute of Education.

Bandura, A. (1997). Self-Efficacy: The Exercise of Control. W.H. Freeman and Company.

Bandura, A. (2002). Social Cognitive Theory in Cultural Context. Applied Psychology, 51, 269-290. https://doi.org/10.1111/1464-0597.00092

Barton, A. C., Tan, C., \& Greenberg, D. (2017). The Makerspace Movement: Sites of Possibilities for Equitable Opportunities to Engage Underrepresented Youth in STEM. Teachers College Record, 119, 1-44.

Bodrova, E., Germeroth, C., \& Leong, D. J. (2013). Play and Self-Regulation: Lessons from Vygotsky. American Journal of Play, 6, 111-123.

Braund, M., \& Reiss, M. (2006). Towards a More Authentic Science Curriculum: The contribution of Out-of-School Learning. International Journal of Science Education, 28, 1373-1388. https://doi.org/10.1080/09500690500498419 
Buchholz, B., Shively, K., Peppler, K., \& Wohlwend, K. (2014). Hands On, Hands Off: Gendered Access in Crafting and Electronics Practices. Mind, Culture, and Activity, 21, 278-297. https://doi.org/10.1080/10749039.2014.939762

Buechley, L. (2013). LilyPad Arduino: E-Textiles for Everyone. In L. Buechley, K. A. Peppler, M. Eisenberg, \& Y. B. Kafai (Eds.), Textile Messages: Dispatches from the World of E-Textiles and Education (pp. 17-28). Peter Lang Publishing. https://doi.org/10.3726/978-1-4539-0941-6

Buechley, L., \& Mako-Hill, B. (2010). LilyPad in the Wild: How Hardware's Long Tail Is Supporting New Engineering and Design Communities. In the 8th ACM Conference on Designing Interactive Systems, New York, August 2010, ACM Press. https://doi.org/10.1145/1858171.1858206

Burge, J. E., Gannod, G. C., Doyle, M., \& Davis, K. C. (2013). Girls on the Go: A CS Summer Camp to Attract and Inspire Female High School Students. In 44th ACM Technical Symposium on Computer Science Education, New York, March 2013. https://doi.org/10.1145/2445196.2445376

Chu, S. L., Quek, F., Bhangaonkar, S., Ging, A. B., \& Sridharamurthy, K. (2015). Making the Maker: A Means-to-an-Ends Approach to Nurturing the Maker Mindset in Elementary-Aged Children. International Journal of Child-Computer Interaction, 5, 11-19. https://doi.org/10.1016/j.ijcci.2015.08.002

Claxton, G. (2015). Schooling for the Real World: Why It Does Not Happen. Learning Beyond the Classroom, 11, 81-93.

Dougherty, D. (2013). The Maker Mindset. In M. Honey, \& D. E. Kanter (Eds.), Design. Make. Play. Growing the Next Generation of STEM Innovators (pp. 7-16). Routledge.

Gershenfeld, A. (2005). Fab: The Coming Revolution on Your Desktop-from Personal Computers to Personal Fabrication. Basic Books.

Godec, S., King, H., \& Archer, L. (2017). The Science Capital Teaching Approach: Engaging Students with Science, Promoting Social Justice. London: UCL Institute of Education.

Ladeji-Osias, J. O., \& Partlow, L. (2017). Board \# 101: Impact of a Year-Round Out-of-School Maker Program on Minority Middle School Boys. In the 2017 ASEE Annual Conference and Exposition, Columbus, Ohio, June 24-June 28, 2017. https://doi.org/10.18260/1-2--27669

Lonescu, T., \& Vasc, D. (2014). Embodied Cognition: Challenges for Psychology and Education. Procedia-Social and Behavioral Sciences, 128, 275-280. https://doi.org/10.1016/j.sbspro.2014.03.156

Maric, J. (2018). The Gender-Based Digital Divide in Maker Culture: Features, Challenges and Possible Solutions. Journal of Innovation Economics and Management, 27, 147-168. https://doi.org/10.3917/jie.027.0147

Marshall, J. A., \& Harron, J. R. (2018). Making Learners: A Framework for Evaluating Making in STEM Education. Interdisciplinary Journal of Problem-Based Learning, 12. https://doi.org/10.7771/1541-5015.1749

Martin, L. (2015). The Promise of the Maker Movement for Education. Journal of Pre-College Engineering Education Research, 5, 30-39. https://doi.org/10.7771/2157-9288.1099

Martin, L., Dixon, C., \& Betser, S. (2018). Iterative Design toward Equity: Youth Repertoires of Practice in a High School Maker Space. Equity and Excellence in Education, 51, 36-47. https://doi.org/10.1080/10665684.2018.1436997

Morocz, R. J., Levy, B., Forest, C., Nagel, R. L., Newstetter, W. C., Talley, K. G., \& Linsey, 
J. S. (2016). Relating Student Participation in University Maker Spaces to Their Engineering Design Self-Efficacy. In the American Society for Engineering Education Annual Conference Proceedings, New Orlean, June 26-June 29, 2016.

https://doi.org/10.18260/p.26070

National Research Council (2015). Identifying and Supporting Productive STEM Programs in Out-of-School Settings. National Academy Press.

Papert, S. (1986). Constructionism: A New Opportunity for Elementary Science Education. A Proposal to the National Science Foundation, Massachusetts Institute of Technology, Media Laboratory, Epistemology and Learning Group, Cambridge, Massachusetts.

Papert, S., \& Harel, I. (1991). Situating Constructionism. In I. Harel, \& S. Papert (Eds.), Constructionism. Ablex Publishing.

Peppler, K., Keune, A., Xia, F., \& Chang, S. (2017). Survey of Assessment in Makerspaces. Open Portfolio Project.

https://makered.org/wpcontent/uploads/2018/02/MakerEdOPP_RB17_Survey-of-Asses sments-in-Makerspaces.pdf.

Peppler, K., Maltese, A., Keune, A., Chang, S., \& Regalla, L. (2015). Survey of Makerspaces, Part II. Open Portfolio Project: Research Brief Series (pp. 44-50). San Francisco: Maker Education Initiative.

Petrich, M., Wilkinson, K., \& Bevan, B. (2013). It Looks Like Fun, but Are They Learning? In M. Honey, \& D. E. Kanter (Eds.), Design. Make. Play. Growing the Next Generation of STEM Innovators (pp. 50-70). Routledge.

Piaget, J. (1962). Play, Dreams, and Imitation in Childhood. Norton.

Scriven, M. (1967). The Methodology of Evaluation. In R. W. Tyler, R. M. Gagne, \& M. Scriven (Eds.), Perspectives of Curriculum Evaluation Chicago (pp. 39-83). Rand McNally.

Searle, K. A., \& Kafai, Y. B. (2015). Boys' Needlework: Understanding Gendered and Indigenous Perspectives on Computing and Crafting with Electronic Textiles. In the Eleventh Annual International Conference on International Computing Education, Omaha Nebraska, July 2015. https://doi.org/10.1145/2787622.2787724

Sheridan, M. D. (1977). Spontaneous Play in Early Childhood: From Birth to Six Years. NFER Publishing. https://doi.org/10.4324/9780203272244

TASCHA [Technology and Social Change Group, University of Washington] (2012). Libraries and Makerspaces: A Revolution? http://tascha.uw.edu/2014/06/libraries-makerspaces-a-revolution/

Taylor, B. (2016). Evaluating the Benefit of the Maker Movement in K-12 STEM Education. Electronic International Journal of Education, Arts, and Science, 2.

Vansteenkiste, M., Simons, J., Lens, W., Sheldon, K. M., \& Deci, E. L. (2004). Motivating Learning, Performance, and Persistence: The Synergistic Effects of Intrinsic Goal Contents and Autonomy-Supportive Contexts. Journal of Personality and Social Psycholo$g y, 87,246 . \underline{\text { https://doi.org/10.1037/0022-3514.87.2.246 }}$

Wilson, M. (2002). Six Views of Embodied Cognition. Psychonomic Bulletin and Review, 9, 625-636. https://doi.org/10.3758/BF03196322

Yin, Y., Hadad, R., Tang, X., \& Lin, Q. (2020). Improving and Assessing Computational Thinking in Maker Activities: The Integration with Physics and Engineering Learning. Journal of Science Education and Technology, 1-26. https://doi.org/10.1007/s10956-019-09794-8 